\title{
Effect of Bio-Phos (Chaetomium globosum) on Castor (Ricinus communis L.) Yield at Different Levels of Phosphorus under Irrigated Conditions
}

\author{
P.M. Vaghasia*, R.L. Davariya and R.N. Daki \\ Main Oilseeds Research Station, Junagadh Agricultural University, Junagadh, Gujarat, India \\ *Corresponding author
}

\begin{tabular}{|c|c|}
\hline \multicolumn{2}{|r|}{ A B S T R A C T } \\
\hline & \multirow{7}{*}{$\begin{array}{l}\text { The field experiments were conducted at the Main Oilseeds Research Station, Junagadh } \\
\text { Agricultural University, Junagadh to assess the response of bio- phos (Chaetomium } \\
\text { globosum) on castor and compared its efficiency with applied inorganic phosphorus } \\
\text { through fertilizer during kharif season of year } 2011-12 \text { to } 2013-14 \text { on medium clay soil } \\
\text { under irrigated conditions. The experiment consisted of eight treatment combinations of } \\
\text { seed treatment with bio-phos @ } 30 \mathrm{~g} \text { inoculants } / 50 \mathrm{~g} \text {. castor seed (cv. GCH 7) seed with } \\
\text { different doses of phosphorus ( } 20 \mathrm{~kg} \text {, } 40 \mathrm{~kg} \text { and } 60 \mathrm{~kg} / \mathrm{ha} \text { ). The seed yield of castor was } \\
\text { increased due to seed inoculation with bio-phos to the tune of } 309 \mathrm{~kg} / \mathrm{ha}, 33 \mathrm{~kg} / \mathrm{ha} \text {, } 188 \\
\mathrm{~kg} / \mathrm{ha} \text { and } 156 \mathrm{~kg} / \mathrm{ha} \text { over sole application of } 0,20,40 \text { and } 60 \mathrm{~kg} \mathrm{P} \mathrm{P}_{5} / \mathrm{ha} \text {, respectively. } \\
\text { The increment in seed yield of castor with bio-phos was higher at } 40 \mathrm{~kg} / \mathrm{ha} \text { applied P and } \\
\text { decreased with addition of inorganic P. Castor seed yield improvement of } 8.35 \% \text {, net } \\
\text { returns of Rs } 36989 / \text { - and B:C ratio of } 2.64 \text { were recorded under application of } 40 \mathrm{Kg} \mathrm{P}_{2} \mathrm{O}_{5} \\
\text { /ha along with seed inoculation of bio-phos. }\end{array}$} \\
\hline Keywords & \\
\hline Castor, Bio-phos, & \\
\hline $\begin{array}{l}\text { Phosphorus, Seed } \\
\text { inoculation, Yield. }\end{array}$ & \\
\hline Article Info & \\
\hline $\begin{array}{l}\text { Accepted: } \\
\text { 21 July } 2017 \\
\text { Available Online: } \\
\text { 10 September } 2017\end{array}$ & \\
\hline & \\
\hline
\end{tabular}

\section{Introduction}

Castor (Ricinus communis L.) is an important non-edible industrial oilseed crop grown in kharif season under rainfed conditions of India and the country holds a premier and dominant position in its production and supplies. Castor oil is most versatile and economically important natural plant product. According to Solvent Extractors' Association (SEA), India's exports of castor oil and derivatives are estimated about 400,000 tonnes worth around $\$ 800$ million during 2014 (Bussiness Standard, 2015). Castor is being grown in many states of India. Castor yield depends on several agronomic factors. Poor fertilizer use efficiency, arid and semiarid environment and light soil are some of cause for poor productivity. Phosphorus is most indispensable mineral nutrient for crop as it helps in better root growth and development and thereby making them more efficient in biological nitrogen fixation. It involves in metabolic activities as a constituent of nucleoproteins, nucleotides and also plays a key role in the formation of energy rich phosphate bond like ADP and ATP. Bio-fertilizers (PSB) can play an important role in meeting the phosphorus requirement of crops solubilization of insoluble phosphorus sources. Plant growth promoting bacteria (PGPR) are a group of free living microorganisms that use different methods to increase plant growth (Glick, 
1995). Some of these bacteria increase $P$ uptake by the plant belongs to the group of phosphate solubilizing bacteria (PSB) and as biological fertilizers are used to increase plant growth and yield (Chen et al., 2006). Phosphorus is added in the form of phosphatidic fertilizers, part of which is utilized by plants and the remainder converted into soluble fixed forms. To circumvent phosphorus deficiency, phosphatesolubilizing microorganisms (PSM) could play an important role in supplying phosphate to plants in a more environmentally-friendly and sustainable manner. Biophos (Chaetomium globosum) is a naturally occurring phosphorus mobilizing organisms when applied through seed treatment, release huge amount of phosphatases, phytase and organic acids which may help in mobilization of native unavailable phosphorus (Tarafdar and Gharu, 2006).

Bio-phos can tolerate moderately high soil temperature prevailing in the arid and semiarid regions. Biophos was prepared from a phosphatase and phytase releasing fungus Chaetomium globosum. Research work on these aspects in castor crop is meager, therefore, the present study was undertaken to assess the role of bio-phos in castor crop under semi-arid conditions.

\section{Materials and Methods}

The field experiment was conducted during rainy seasons of 2011-12, 2012-13 and 201314 at Main Oilseeds Research Station, Junagadh Agricultural University, Junagadh, and Gujarat, India under irrigated conditions. The soil of the experimental plot was clayey in texture and slightly alkaline in reaction. The soil has an organic carbon content of 0.67 per cent and was low in available nitrogen $211 \mathrm{~kg} / \mathrm{ha}$, phosphorus $29.0 \mathrm{~kg} / \mathrm{ha}$ and high in potash $324 \mathrm{~kg} / \mathrm{ha}$. The moisture content of the experimental plot at field capacity and permanent wilting point were 27.4 and 13.8 per cent, respectively, while the bulk density was $1.34 \mathrm{gcm}^{-3}$. The experiment was laid out in randomized block design with three replications. The experiment consisted of eight treatment combinations of seed treatment with bio-phos @ 30g. Inoculants/ 50 g. castor seed (cv. GCH 7) seed with different doses of phosphorus $(20 \mathrm{~kg}, 40 \mathrm{~kg}$ and $60 \mathrm{~kg} / \mathrm{ha}$ ). Seed treatment of bio-phos was done by sticking solution (jaggary solution@125g/liter water) on seeds. 30g. inoculants were sprinkled on the seeds and it was mixed thoroughly.

Seeds were air dried in shade after treatment and then used for sowing. A recommended dose of nitrogen, potash and seed rate was applied. The crops were sown under rainy season but after cessation of monsoon five irrigations each of $50 \mathrm{~mm}$ depth were given to castor crop at an interval of 15 days. Pest and disease control measures were taken as and when required. Castor picked at 90, 120, 150 and 180 days after sowing. The rainfall received during the crop growing season of 2011-12, 2012-13 and 2013-14 was $525 \mathrm{~mm}$, $1520 \mathrm{~mm}$ and $1271 \mathrm{~mm}$, respectively. All the data obtained were statistically analyzed by using the Panse and Sukhatme (1985) procedure.

\section{Results and Discussion}

\section{Growth and yield attributes}

Results presented in table 2 revealed that the growth and yield attributes significantly influenced by different treatments. The highest plant height $(72.53 \mathrm{~cm})$, number of branches per plant (6.22), number of spikes per plant (9.22), capsules per spikes (77.00) and length of main spike $(47.94 \mathrm{~cm})$ were significantly recorded by seed inoculation with bio-phos@30g inoculants $/ 50 \mathrm{~g}$ castor seed $+40 \mathrm{~kg} \mathrm{P}_{2} \mathrm{O}_{5} / \mathrm{ha}$. In pooled results which 
was remained at par with application of $40 \mathrm{~kg}$ $\mathrm{P} 2 \mathrm{O} 5 / \mathrm{ha}, 60 \mathrm{~kg} \mathrm{P}_{2} \mathrm{O}_{5} / \mathrm{ha}$, seed inoculation with bio-phos@30g inoculants $/ 50 \mathrm{~g}$ castor seed $+60 \mathrm{~kg} \mathrm{P}_{2} \mathrm{O}_{5} / \mathrm{ha}$. Some of these bacteria increase $\mathrm{P}$ uptake by the plant belongs to the group of phosphate solubilizing bacteria and as biological fertilizers are used to increase plant growth and yield (Chen et al., 2006). Microorganisms with phosphate solubilizing potential increase the availability of soluble phosphate and enhance the plant growth (Kucey et al., 1989; Ponmurugan and Gopi, 2006). Rhizospheric microorganisms can interact positively in promoting plant growth similar finding was also reported by Tomar et al., (2004). Oil per cent was significantly higher at seed inoculation with bio-phos @ $30 \mathrm{~g}$.inoculants $/ 50 \mathrm{~g}$ castor seed $+20 \mathrm{~kg}$ $\mathrm{P}_{2} \mathrm{O}_{5} /$ ha which was at par with application of $20 \mathrm{~kg} \quad \mathrm{P}_{2} \mathrm{O}_{5} / \mathrm{ha}, \quad 40 \quad \mathrm{~kg} \quad \mathrm{P}_{2} \mathrm{O}_{5} / \mathrm{ha}$, seed inoculation with bio-phos @ $30 \mathrm{~g}$ inoculants $/ 50 \mathrm{~g}$ castor seed $+40 \mathrm{~kg} \mathrm{P}_{2} \mathrm{O}_{5} / \mathrm{ha}$. Similar finding was also reported by Tomar et al., (2004) who observed that inoculation and phosphorus application increased oil contents of soybean. Similar experimental results have been reported by Singh et al., (2013) and Yadav and Yadav (2015).

\section{Seed yield}

The results showed that seed yield of castor were significantly influenced by different treatments (Table 1). Significantly higher seed yield (1937 kg/ha) was recorded when crop was fertilized with $60 \mathrm{~kg} \mathrm{P}_{2} \mathrm{O}_{5} / \mathrm{ha}$. But, it remained at par with $60 \mathrm{~kg} \mathrm{P}_{2} \mathrm{O}_{5} /$ ha and seed treatment with bio-phos @ 30g inoculants $/ 50 \mathrm{~g}$ castor seed (1744 kg/ha) during 2011-12. The results indicated that there was a linear response of added phosphorus to seed yield from 0 level (1750 $\mathrm{kg} / \mathrm{ha})$ to $20 \mathrm{~kg} \mathrm{P}_{2} \mathrm{O}_{5} / \mathrm{ha}(2187 \mathrm{~kg} / \mathrm{ha}), 40 \mathrm{~kg}$ $\mathrm{P}_{2} \mathrm{O}_{5} / \mathrm{ha}(2254 \mathrm{~kg} / \mathrm{ha})$ and $60 \mathrm{~kg} \mathrm{P}_{2} \mathrm{O}_{5} / \mathrm{ha}$ (2408 kg/ha). Significantly higher seed yield $(2552 \mathrm{~kg} / \mathrm{ha})$ was recorded at seed treated with bio-phos@30g.inoculents / 50 g castor seed with $40 \mathrm{~kg} \mathrm{P}_{2} \mathrm{O}_{5} / \mathrm{ha}$, but remained at par with seed treatment with bio- phos @30g inoculants $/ 50 \mathrm{~g}$ castor seed $+20 \mathrm{~kg} \mathrm{P}_{2} \mathrm{O}_{5} / \mathrm{ha}$, $40 \mathrm{~kg} \mathrm{P}_{2} \mathrm{O}_{5} / \mathrm{ha}, 60 \mathrm{~kg} \mathrm{P}_{2} \mathrm{O}_{5} / \mathrm{ha}$ and seed treatment with bio-phos @ $30 \mathrm{~g}$ inoculants $/ 50 \mathrm{~g}$ castor seed $+60 \mathrm{~kg} \mathrm{P}_{2} \mathrm{O}_{5} / \mathrm{ha}$. During 2012-13. While during 2013-14, the application of 60 $\mathrm{kg}_{2} \mathrm{O}_{5} /$ ha together with bio-phos resulted in distinct improvement in seed yield (3279 $\mathrm{kg} / \mathrm{ha}$ ) over the rest of the treatments except for $40 \mathrm{~kg} \mathrm{P}_{2} \mathrm{O}_{5} / \mathrm{ha}+$ bio-phos, which indicted the efficacy of bio-phos upto $40 \mathrm{~kg} \mathrm{P}_{2} \mathrm{O}_{5} / \mathrm{ha}$. Three years pooled results indicated that there was a linear response of seed yield due to increased phosphorus application from 0 to 60 $\mathrm{kg} \mathrm{P}_{2} \mathrm{O}_{5} /$ ha. Significantly higher seed yield was recorded by seed treated with bio-phos @ $30 \mathrm{~g}$.inoculants / 50g. Castor seed $+60 \mathrm{~kg}$ $\mathrm{P}_{2} \mathrm{O}_{5} / \mathrm{ha}(2500 \mathrm{~kg} / \mathrm{ha})$, but it remained on same bar with seed treatment of bio-phos @ $30 \mathrm{~g}$.inoculants / 50g. Castor seed $+40 \mathrm{~kg}$ $\mathrm{P}_{2} \mathrm{O}_{5} / \mathrm{ha}(2437 \mathrm{~kg} / \mathrm{ha})$ and $40 \mathrm{~kg} \mathrm{P}_{2} \mathrm{O}_{5} / \mathrm{ha}$ and $60 \mathrm{~kg} \mathrm{P}_{2} \mathrm{O}_{5} /$ ha. The effect of bio-phos was further enhanced while $\mathrm{P}$ was supplemented with inorganic fertilizer. This was due to release huge amount of phosphatases, phytase and organic acids which may help in mobilization of native unavailable phosphorus by bio-phos (Tarafdar and Gharu, 2006). Some of these bacteria increase $\mathrm{P}$ uptake by the plant belongs to the group of phosphate solubilizing bacteria and as biological fertilizers are used to increase plant growth and yield (Chen et al., 2006). The PSB solubilize the fixed soil $\mathrm{P}$ and applied phosphates resulting in higher crop yields (Gull et al., 2004). The higher value of castor seed yield was result of higher value of different growth and yield contributing characters. These findings are in the conformity with the result of Singh et al., (2013) and Yadav and Yadav (2015).The lower seed yield recorded in treatment where control was due to no application of phosphorus and bio-phos. 
Table.1 Effect different treatments on seed yield and economics of castor

\begin{tabular}{|c|c|c|c|c|c|c|c|c|c|}
\hline \multirow[b]{2}{*}{ Tret. No. } & \multirow[b]{2}{*}{ Treatments } & \multicolumn{4}{|c|}{ Seed yield (kg/ha) } & \multicolumn{4}{|c|}{ Economics } \\
\hline & & 2011 & 2012 & 2013 & Pooled & $\begin{array}{l}\text { Gross return } \\
\text { (Rs/ha) }\end{array}$ & $\begin{array}{l}\text { Cost of } \\
\text { cultivation } \\
\text { Rs/ha) }\end{array}$ & $\begin{array}{l}\text { Net return } \\
\text { (Rs/ha) }\end{array}$ & $\mathrm{B}: \mathrm{C}$ ratio \\
\hline $\mathrm{T}_{1}$ & Control $\left(\mathrm{No} \mathrm{P}_{2} \mathrm{O}_{5}\right)$ & 1099 & 1750 & 1956 & 1601 & 64058 & 34500 & 29558 & 1.86 \\
\hline $\mathrm{T}_{2}$ & $\begin{array}{l}\text { Seed treatment with bio- } \\
\text { phos @ 30g.inoculants / } \\
50 \mathrm{~g} . \text { castor seed }\end{array}$ & 1273 & 2052 & 2406 & 1910 & 76416 & 34800 & 41616 & 2.20 \\
\hline $\mathrm{T}_{3}$ & $20 \mathrm{~kg} \mathrm{P}_{2} \mathrm{O}_{5} / \mathrm{ha}$ & 1505 & 2187 & 2452 & 2048 & 81916 & 35738 & 46178 & 2.29 \\
\hline $\mathrm{T}_{4}$ & $\mathrm{~T}_{2}+20 \mathrm{~kg} \mathrm{P} \mathrm{O}_{5} / \mathrm{ha}$ & 1384 & 2248 & 2610 & 2081 & 83226 & 36038 & 47188 & 2.31 \\
\hline $\mathrm{T}_{5}$ & $40 \mathrm{~kg} \mathrm{P}_{2} \mathrm{O}_{5} / \mathrm{ha}$ & 1921 & 2254 & 2572 & 2249 & 89963 & 36689 & 53275 & 2.45 \\
\hline $\mathrm{T}_{6}$ & $\mathrm{~T}_{2}+40 \mathrm{~kg} \mathrm{P}_{2} \mathrm{O}_{5} / \mathrm{ha}$ & 1644 & 2552 & 3116 & 2437 & 97492 & 36989 & 60504 & 2.64 \\
\hline $\mathrm{T}_{7}$ & $60 \mathrm{~kg} \mathrm{P}_{2} \mathrm{O}_{5} / \mathrm{ha}$ & 1937 & 2408 & 2688 & 2344 & 93761 & 37588 & 56173 & 2.49 \\
\hline $\mathrm{T}_{8}$ & $\mathrm{~T}_{2}+60 \mathrm{~kg} \mathrm{P} \mathrm{P}_{5} / \mathrm{ha}$ & 1744 & 2478 & 3279 & 2500 & 100004 & 37888 & 62116 & 2.64 \\
\hline & S.Em \pm & 91 & 117 & 112 & 101 & - & - & - & - \\
\hline & C.D. $(\mathrm{P}=0.05)$ & 277 & 354 & 343 & 305 & - & - & - & - \\
\hline & C.V.\% & 10.1 & 9.0 & 7.7 & 8.8 & - & - & - & - \\
\hline
\end{tabular}

Market price: Castor: Rs. 40/kg, Cost of inputs (Rs. /kg): Urea -6.50, DAP- 25.18, Bio-phos: 100.00

Table.2 Effect of different treatments on growth and yield attributes of castor (Pooled data of three years)

\begin{tabular}{|c|c|c|c|c|c|c|c|c|c|c|}
\hline $\begin{array}{l}\text { Tret. } \\
\text { No. }\end{array}$ & Treatments & $\begin{array}{c}\text { Plant } \\
\text { Stand /ha }\end{array}$ & $\begin{array}{l}\text { Plant height } \\
(\mathrm{cm})\end{array}$ & $\begin{array}{c}\text { No. of } \\
\text { Branches/ Plant }\end{array}$ & $\begin{array}{c}\text { No. of Spikes / } \\
\text { Plant }\end{array}$ & $\begin{array}{c}\text { No. of Internodes/ } \\
\text { plant }\end{array}$ & $\begin{array}{l}\text { Capsules/ } \\
\text { spike } \\
\end{array}$ & $\begin{array}{l}\text { Length of main } \\
\text { spike }(\mathrm{cm})\end{array}$ & $\begin{array}{c}100 \text { seed } \\
\text { wt }(\mathrm{g})\end{array}$ & Oil \% \\
\hline $\mathrm{T}_{1}$ & Control & 13462 & 51.09 & 4.22 & 6.89 & 18.00 & 52.78 & 37.78 & 31.90 & 47.6 \\
\hline $\mathrm{T}_{2}$ & $\begin{array}{l}\text { Seed treatment with bio-phos @ } \\
\text { 30g.inoculants / 50g. castor seed }\end{array}$ & 13423 & 60.80 & 5.00 & 8.00 & 18.44 & 68.89 & 44.73 & 32.57 & 49.4 \\
\hline $\mathrm{T}_{3}$ & $20 \mathrm{~kg} \mathrm{P}_{2} \mathrm{O}_{5} / \mathrm{ha}$ & 13557 & 60.87 & 5.22 & 8.78 & 19.44 & 70.89 & 43.67 & 33.38 & 49.9 \\
\hline $\mathrm{T}_{4}$ & $\mathrm{~T}_{2}+20 \mathrm{~kg} \mathrm{P}_{2} \mathrm{O}_{5} / \mathrm{ha}$ & 13457 & 62.70 & 5.33 & 8.22 & 19.44 & 71.67 & 44.11 & 33.14 & 50.7 \\
\hline $\mathrm{T}_{5}$ & $40 \mathrm{~kg} \mathrm{P}_{2} \mathrm{O}_{5} / \mathrm{ha}$ & 13470 & 61.23 & 6.11 & 9.00 & 18.78 & 72.89 & 45.00 & 32.92 & 50.0 \\
\hline $\mathrm{T}_{6}$ & $\mathrm{~T}_{2}+40 \mathrm{~kg} \mathrm{P}_{2} \mathrm{O}_{5} / \mathrm{ha}$ & 13529 & 72.53 & 6.22 & 9.22 & 18.67 & 77.00 & 47.94 & 33.43 & 50.1 \\
\hline $\mathrm{T}_{7}$ & $60 \mathrm{~kg} \mathrm{P}_{2} \mathrm{O}_{5} / \mathrm{ha}$ & 13639 & 63.13 & 5.67 & 8.78 & 19.22 & 72.56 & 46.00 & 33.37 & 48.9 \\
\hline $\mathrm{T}_{8}$ & $\mathrm{~T}_{2}+60 \mathrm{~kg} \mathrm{P}_{2} \mathrm{O}_{5} / \mathrm{ha}$ & 13510 & 64.98 & 5.89 & 8.67 & 19.33 & 74.56 & 47.00 & 33.21 & 49.5 \\
\hline & S.Em \pm & 164 & 2.46 & 0.26 & 0.27 & 0.52 & 1.89 & 1.55 & 0.42 & 0.4 \\
\hline & C.D. $(\mathrm{P}=0.05)$ & NS & 7.02 & 0.73 & 0.77 & NS & 5.41 & 4.71 & NS & 1.0 \\
\hline & C.V.\% & 3.64 & 11.87 & 14.09 & 9.58 & 8.24 & 8.10 & 7.14 & 3.81 & 2.2 \\
\hline
\end{tabular}




\section{Economics}

Economics of different treatments are presented in table 1. Gross realization, cost of cultivation, net realization and $\mathrm{B}: \mathrm{C}$ ratio of different treatments was worked out on the basis of current market prices of castor and inputs used.

The results indicated that inoculation of biophos $+40 \mathrm{~kg} \mathrm{P}_{2} \mathrm{O}_{5} /$ ha recorded higher gross return (Rs. 97492/ha), net return (Rs. 60504/ha) and $\mathrm{B}: \mathrm{C}$ ratio (2.64) in pooled results.

From the three years data it is concluded that seed treatment of bio-phos @ 30g inoculants $/ 50 \mathrm{~g}$. Castor seed + application of 40 $\mathrm{kg} \quad \mathrm{P}_{2} \mathrm{O}_{5} / \mathrm{ha}$ was more productive and remunerative for castor under irrigated conditions.

\section{References}

Anonymous, 2014. Annual Report for 2013-14 of AICRP on castor, Directorate of Oilseeds Research, Hyderabad, AP.

Chen, Y. P., Rekha, P.D., Arun, AB, Shen, F.T., Lai, W.A., Young, C.C. 2006. Phosphate solubilizing bacteria from subtropical soil and their tricalcium phosphate solubilizing abilities. Applied Soil Ecology, 34 (1): 33-41.

Glick, B. R., 1995. The enhancement of plant growth by free living bacteria. Canadian Journal of Microbiology, 41 (2): 109-114.

Gull, M., F. Hafeez, Y., Saleem, M. and Malik, K. A. 2004. Phosphorus uptake and growth promotion of chickpea by coinoculation of mineral phosphate solubilizing bacteria and a mixed rhizobial culture. Aust. J. Exp. Agric. 44:623-628.

Kucey, R. M. N., Janzen, H. H. and Legget, M.
E. 1989. Microbial mediated increases in plant available phosphorus. Adv. Agron. 42:199- 228

Panse, V. G., and Sukhatme, P. V. 1985. Statistical methods for agricultural workers. ICAR Pub. New Delhi, pp: 296.

Ponmurugan, P., and Gopi, C. 2006. Distribution pattern and screening of phosphate solubilizing bacteria isolated from different food and forage crops. J. Agron. 5:600-604.

Singh, I., Chawra, R. S., Rathore, M. S. and Tarafdar, J. C. 2013. Response of biophos to castor at varying phosphorus levels under irrigated condition. Green Farming, 4(1):37-39.

Son, T. T. N., Diep, C. N. and Giang, T. T. M. 2006. Effect of bradyrhizobia and phosphate solubilizing bacteria application on Soybean in rotational system in the Mekong delta. Omonrice. 14:48-57

Tarafdar, J.C., and Gharu, A. 2006. Mobilization of organic and poorly soluble phosphates by Chaetomium globosum. Applied Soil Ecology, 32:273283.

Tomar, S. S., Singh, R., \& Singh, P. S. 2004. Response of phosphorus, sulphur and Rhizobium inoculation on growth, yield and quality of soybean. Prog. Agric., 4(1), $72-73$

Yadav, J. S., and Yadav, S. S. 2015. Effect of bio-phos (Chaetomium globosum) on castor at varying levels of phosphorus application under irrigated conditions. In: National seminar on Strategic interventions to enhance oilseeds production in India, Indian Society of Oilseeds Research, Hyderabad, Feb. 1921, 2015. Extended Summery pp. 183185.

\section{How to cite this article:}

Vaghasia, P.M., R.L. Davariya and Daki, R.N. 2017. Effect of Bio-Phos (Chaetomium globosum) on Castor (Ricinus communis L.) Yield at Different Levels of Phosphorus under Irrigated Conditions. Int.J.Curr.Microbiol.App.Sci. 6(9): 1974-1978. doi: https://doi.org/10.20546/ijcmas.2017.609.241 